\title{
THE SERVICE FAILURE AND RECOVERY STRATEGIES IN LOGISTICS SERVICE SECTOR
}

\author{
Nazlı Gülfem GIDENER ÖZAYDIN1
}

\begin{abstract}
The customer's perspective on the service quality is highly significant in logistics service sector as in any other sector. The biggest threat posed by service failures is the possibility of negatively influencing the customer's perceptions on the service they receive and the service provider they work with. Therefore, service providers must implement an effective recovery strategy in the shortest time possible and satisfy the customers once again. Service providers which fail to satisfy their customers are expected to suffer a great decrease in their performance due to troubles related with competitive advantage, sustainability, profits and financial stamina, customer retention and attracting new customers. Thus, first service failures must be identified and recovered from as quickly as possible and the reasons underlying the occurrence of these service failures must be explored and removed to ensure it won't happen again. This study has been designed to explore the general and specific business to business service quality, the service failure and recovery strategies dimensions in logistics sector and aims to contribute to the business to business marketing literature.
\end{abstract}

Keywords: Service Quality, Logistics Sector, Service Failures, Recovery Strategies.

\section{LOJİSTIKK HİZMET SEKTÖRÜNDE HİZMET HATALARI VE TELAFİ STRATEJILLERI}

\section{ÖZ}

Tüm sektörler gibi lojistik hizmet sektöründe de sunulan hizmetin kalitesi ve müşterilerin konuyla ilgili algıları büyük önem taşımaktadır. Yaşanan hizmet hatalarının yarattığı en büyük tehlike müşterilerin aldıkları hizmet ve birlikte çalıştıkları hizmet sağlayıcı hakkındaki algılarını kötü yönde etkileme olasılığıdır. Bu bağlamda, hizmet sağlayıcıların en kısa sürede, etkin bir telafi stratejisi uygulayarak müșterileri yeniden tatmin etmeleri gerekmektedir. Müşteri tatminini sağlayamayan hizmet sağlayıcıların, rekabetçi üstünlük kazanma, sürdürülebilirlik, kazanç ve dolayısıyla finansal durum, müşterileri elde tutma ve yeni müşteri kazanma gibi konularda sıkıntı

1 Dr., Dokuz Eylül University, Maritime Faculty, Department of Logistics Management, ngg.ozaydin@deu.edu.tr. 
çekmesi ve performansında büyük düşüş yaşaması beklenmektedir. Dolayısıla yaşanan hataların kızı şekilde fark edilmesi ve telafi edilmesinin ardından altında yatan nedenler de araștırılmalı ve ortadan kaldırılmalıdır. Bu çalışma, işletmeler arası hizmet kalitesi, hizmet hataları ve telafi stratejileri boyutlarının genel ve özel olarak lojistik sektöründe araştırılması için tasarlanmış olup işletmeler arası pazarlama ve lojistik yazınına katkı sağlamayı amaçlamaktadır.

Anahtar Kelimeler: Hizmet Kalitesi, Lojistik Sektörü, Hizmet Hataları, Telafi Stratejileri.

\section{Introduction}

The importance of the quality of the service provided can be observed most severely through its absence. The negative effects of low quality service are: additional costs related with providing the customer with the same service or recovering from the service failure, lost customers, negative word of mouth and the decrease in overall employee morale (Öztürk, 2000). The service recovery is an additional cost since it requires additional activities to be undertaken by the service provider such as compensation, discounts etc. The negative word of mouth may restrict the service provider's ability to attract new customers and may even cause the service provider to lose the existing customers.

The service quality is more complex than of a product since the customer is highly involved and has an opinion on many aspects of the service production process and consequently the service provider. The functional quality which refers to how the service is provided is just as important as the technical quality which refers to what was provided (Grönroos, 1982). However, this fact is usually ignored or overseen by the majority of service providers especially service providers that operate in a business to business (b2b) service setting like logistics service providers. The possible reason for $b 2 \mathrm{~b}$ service providers to overlook the importance of functional quality may be due to the level of professionalism of customers in b2b services.

However, it is vital for service providers to observe the service failures experienced by customers thoroughly, to guarantee recovery strategies for these failures in a short period of time, to find out the reasons underlying the failure and to prevent these failures from reoccurring in the future in order to sustain the service quality of the firm (Öztürk, 2000). 
This study aims to explore the general and specific business to business service quality literature and the dimensions of service failure and recovery strategies in general and in the logistics sector in order to contribute to the business to business marketing and logistics literature and practice. In order to achieve these goals, the service failure and recovery literature has been reviewed with diligence and the significant determinants for high service quality, customer retention and sustainable logistics service businesses were underlined. This paper starts with the logistics service quality, its importance and determinants and continues with introducing the service failure and service recovery concepts in general. Afterwards, service failures in logistics services, service failure type, magnitude and frequency are explained. Then, service recovery and recovery response time are explored. Finally, expected outcomes of service failures and recovery strategies are given and the paper is concluded with highlighting the most crucial determinants of logistics service quality, the importance of appropriately handling logistics service failures and implementing effective recovery strategies and suggestions for practitioners.

\section{Logistics Service Quality}

The quality of the service customers receive have a huge impact on the company's ability to retain customers or attracting new ones, therefore, any failure in logistics customer service and its effects on the overall perceptions of the customer should be highlighted (Oflaç et al., 2012). Thus, the quality of the logistics services is highly significant in the sense that it will decide the logistics service provider's ability to reach high customer retention rates and receiving positive word of mouth through satisfied customers. Nonetheless there are gaps in service design and delivery that disable service providers to comprehend their customers' needs and expectations. These gaps are: The knowledge gap, the policy gap, the delivery gap, the communications gap, the perceptions gap and the service quality gap (Lovelock and Wirtz, 2011). The concept of gaps was first introduced to the literature by Parasuraman et al. (1985) to point out why service businesses might be failing. Although the initial gap model focused on a consumer market point of view, the fact that $b 2 b$ markets also involve individuals should not be ignored. The knowledge gap stands for the difference between management's perception of customer needs and expectations and the actual needs and expectations of the customer. The policy gap is the difference between management's perception of customers' 
expectation and the established service quality standards. Delivery gap refers to the promised service delivery and the actual performance of the service delivery. The communications gap refers to the difference between what the service provider company thinks it's communicating with its customers and what the customers are actually getting out of it. The perceptions gap underlines what was delivered to the customer and how the customers evaluated received service. And finally, service quality gap is the difference between the expected service quality of customers with the perception of the quality of the service received (Lovelock and Wirtz, 2011). All these gaps should be examined in order for the logistics service providers to prevail in the b2b service sector. In addition, Bienstock et al., (1996) found out that the most important determinants of physical distribution service quality are related with the timeliness and the availability of the service.

The logistics service quality has been examined through reliability, timely responsiveness, accuracy in documentation, accuracy in information, service fulfillment, problem solving ability and empathy dimensions as well (Stewart, 1995; Beamon, 1999; Gunasekaran et al., 2001, Mentzer et al., 2001; Panayides and So, 2005). Furthermore, logistics service quality has also been examined from two different perspectives: objective and subjective quality (Saura et al., 2008). The first one is focused on the delivery and the process of the transport and the second on is focused on the customer's perspective (Garvin, 1984; Parasuraman et al, 1988).

The strength of the tie between the logistics service provider and its customer has an impact on the economic outcomes of the company. This is due to the service is being provided in a coordinated manner and eventually leading to higher levels of logistics service quality. The service quality, productivity and exchange processes are directly affected by the information exchange, accuracy, flexibility and solidarity due to the strength of the relationship between the logistics service provider and its customer (Panayides and So, 2005). Finally, it is suggested that logistics service providers should enhance the perceived quality of customers in order to achieve higher customer satisfaction rates and ensure an increase in their market share (Qureshi et al., 2007). Hence, it is clear that the most crucial part of the logistics service quality is the customer's perception since it influences the service provider's market share and the financial stamina. 


\section{The Concept of Service Failure and Service Recovery}

As the way of conducting business alters continuously in time, the requirements for the both ends of a business transaction vary. Since, the distance between companies are decreasing and partnership like relationships are being formed, it is getting clear that understanding what lies beneath the failures of service provider companies is gaining importance (Flores and Primo, 2008).

Furthermore, switching in business services customers is dependent on switching costs, interpersonal relationships, attractiveness of the alternatives, service recovery and inertia (White and Yanamandram, 2007). Therefore, the importance of relationships in $\mathrm{b} 2 \mathrm{~b}$ service sector becomes evident.

Service failures and recoveries have been investigated thoroughly in the service literature both in B2C and B2B contexts. There are some similarities and some variance in between the $\mathrm{B} 2 \mathrm{C}$ and B2B service literature to be noted. First of all both literature considers the type (Murray and Schlacter, 1990; Bolton and Drew, 1992; Bitner et al., 1990; Zeithaml et al., 1996; Bolton, 1998; Smith et al., 1999), severity (Weun et al., 2004; Craighead et al., 2004; Tax et al., 1998; Blodgett et al., 1997; Hoffman et al., 1995; Richins, 1987; Gilly and Gelb, 1982) the magnitude of the service failure (Smith et al., 1999; Zhu et al., 2004; Bolton, 1998; Bolton and Drew, 1992; Murray and Schlacter, 1990; Zeithaml et al., 1996).

Second, both contexts mostly categorize the service recovery in utilitarian and symbolic manners (Smith et al 1999; Bagozzi, 1975; Zhu et al., 2004). The utilitarian service recovery aims to recover through economic outcomes for the customer such as: compensation, discount and expense share whereas symbolic recovery aims to recover through emotional support such as: assistance, apology and empathy.

\subsection{Service Failures in Logistics Services}

The standards customers evaluate the quality of the service they receive are service expectations and either through satisfying or exceeding those expectations service providers may keep their customers satisfied (Swanson and Hsu, 2009).

The management of service failures is complicated due to; the simultaneity of production and consumption (Michel, 2001) and the challenge of carrying out satisfactory recovery. The first implies that, when service failures actually occur, the presence of customers makes it almost impossible to recover from the failure without letting customers know something went wrong. Even more, 
considering the high level of human involvement in many services and the simultaneity of production and consumption, the occurrence of service failures are almost inevitable (Boshoff and Leong, 1998). In addition, the occurrence of the service failure does not indicate that the logistics service provider is inadequate; even the best of service providers makes mistakes and even flawless service is impossible the way the service provider reacts to customers dissatisfaction is key (Durvasula et al., 2000). Therefore, it can be concluded that the service failure is expected and presents a challenge for the service provider. Whether the service providers rise above the challenge and improve their existing relationships with their customers or fail to meet expectancies and risk losing the customer is solely up to them.

It must be noted that both $\mathrm{B} 2 \mathrm{C}$ and $\mathrm{B} 2 \mathrm{~B}$ contexts are similar in customer expectations and perceptions related with failure that in a sense that it's still an individual making the decisions on the customers' end whether it is for themselves or for the company they work for (Chou et al., 2009). However, it must be noted that within the B2B services perspective critical incidents have a higher impact since they usually create major economic consequences (van Doorn and Verhoef, 2008). In addition, the differences between B2C and B2B service environments in failure recovery perspective are: B2B failure could have greater chance of damage since it can affect both the company and the customers of the buying company, the involvement of multiple customers on the buyer company's side, the influence of the relationship between the buyer and the supplier on the perception of failure and the recovery (e.g. interdependence levels between companies and their suppliers) and finally the impact of operational features and legal limits on customer satisfaction (e.g. long term contracts between parties) (Flores and Primo, 2008).

Accepting that failures are undesirable yet inevitable, whenever a failure occurs the speed and the way companies recover influence customer responses immensely (Swanson and Hsu, 2009; Smith et al., 1999; Chou et al., 2009), and the way the company responds holds the potential to either restore customer satisfaction while reinforcing loyalty or to aggravate the situation and lose the customer (Smith et al., 1999). In addition, the applied recovery should match the service failure and the expectation of the customer to avoid any mismatches and lost opportunities for customer satisfaction, loyalty and retention (Craighead et al., 2004). 
The most important components of logistics services are accuracy of transit/ delivery time, shipment pickups, shipment delivery, recovery from shipment delivery problems, tracking and tracing, proofs of delivery, customer service, billing, personnel attitude, quoting rates, order fill quality, delivery/ order cycle time, post-order service, and credit services and policies (Harding, 1998). Therefore, the most significant service failures are expected to arise from aforementioned logistics service components. Furthermore, it must once again be underlined that due to the time sensitivity of logistics services all services must be recovered from in a timely manner, in order to limit the negative impact of the service failure.

Service failure management should be an integral part of customer service rather than a reactive ad hoc process (Brinsmead, 2007) for sustainability purposes. The service failure recovery is an irreplaceable part of the service provided, most importantly to maintain the excellence and it is a fundamental asset of the company and the chance it presents for restoring or even improving the relationship between the service provider and the customer (Flores and Primo, 2008; Hart et al., 1989; Swanson and Hsu, 2009; Ok et al., 2005). The possibility to improve the existing relationship is due to the "service recovery paradox".

The service recovery paradox which addresses the "question of whether customers who experience a failure followed by superior recovery might rate their satisfaction high or even higher than they would have had no failure occurred" which was partially supported by McCollough and Bharadwaj (1992) and McCollough et al. (2000) should be considered (Weun et al., 2004). Also, the increase in the overall service satisfaction in the occurrence of a critical incident should also be taken into consideration (van Doorn and Verhoef, 2008). After all, critical incidents may revive the customer relationship and enhance the customer loyalty if handled appropriately (van Doorn and Verhoef, 2008).

\subsubsection{Service Failure Types}

There are two different types of failure which are core and supplementary failures (Lovelock and Wirtz, 2011) also known as outcome failure and process failure (Grönroos, 1988, Parasuraman et al., 1991; Keaveney, 1995; Smith et al., 1999; Michel, 2001). The occurrence of an outcome failure is worse for the company since it is a core failure and implicates a higher risk of losing the customer when compared to a process failure. The outcome failure motivates the service provider to put more effort into the recovery than process 
failure (Chou et al., 2009; Bitner et al., 1990; Hoffman et al., 1995; Keaveney, 1995; Mohr and Bitner, 1995; Grönroos, 1988; Parasuraman et al. 1985; Smith et al., 1999).

The outcome failure is where the customer does not receive the service paid for, whereas the process failure refers to a disruption whilst receiving the aforementioned service (Smith et al., 1999). Moreover, literature suggests that the recovery strategy to be implemented must be compatible with the experienced service failure.

Consequently, if the service failure created an economic loss for the customer the related recovery must include economic resource exchange. Moreover, the compensation is considered as an economic resource and is to be expected when a core service failure occurs. On the other hand apology and company initiation are considered to be social resources and are expected when a process service failure occurs (Smith et al., 1999).

\subsubsection{Service Failure Magnitude}

The service failure severity is the perception of the customer on the intensity of the problem, in other words how intense the problem is for the customer in terms of money, time and inconvenience (Weun et al, 2004; Craighead et al., 2004).

The influence of service failure severity on satisfaction, trust, loyalty, customer retention, commitment and negative word-ofmouth and the evaluation of the service provider post-failure have been pointed out (Weun et al., 2004; Craighead et al., 2004). The severity of the service failure directly influences the required recovery (Levesque and McDougall, 2000). The more intense (severe) the problem is perceived; the greater will be the loss in customer's point of view (Weun et al., 2004). It has also been argued that even though after receiving adequate service recovery the perceived loss still will be greater due to prospect theory and mental accounting principles (Kahneman and Tversky, 1979; Smith et al., 1999; Thaler, 1985; Weun et al., 2004).

In addition, customers expect different recoveries depending on the severity of the experienced service failure and the applied recovery should match the service failure at hand (Smith et al., 1999; Levesque and McDougall, 2000; Craighead et al., 2004; Bradley and Sparks, 2012). When a service failure occurs, the level of required recovery to restore perceived justice will be determined by the magnitude of the failure. Moreover the smaller the magnitude of the 
service failure the greater chance of recovery impacting the customer's evaluation positively (Smith et al., 1999).

Severe service failures have been identified to decrease the likelihood that a customer will desire to continue the relationship with the service provider (Keaveney, 1995; Craighead et al., 2004). However, customers are also more likely to purchase high-criticality services from a high-end service provider and are willing to pay more for it (Levesque and McDougall, 2000). In addition, Zeithaml et al (1993), suggests that customer' zone of tolerance for service failures has an accordion like movement and when the service failure is experienced the zone of tolerance will be narrowed due to an expectation increase which will most likely result in dissatisfaction (Gilly and Gelb, 1982; Hoffman et al., 1995).

\subsubsection{Service Failure Frequency}

The service failure frequency is both related with the failure itself, the familiarity level of the customer to the failure and the prior experience with the service provider since B2B relationships tend to be long-term relationships. Prior experience with the company may influence the customer's evaluations of the service failure (Smith et al., 1999). The customers' prior experience with the service provider company affects the recovery requirements (Bolton, 1998; Bolton and Drew, 1991, 1992; Tax et al., 1998; Zeithaml et al., 1996; Zhu et al., 2004; Primo et al., 2007). The reason behind the influence of prior experience is that the prior experience is that past experiences of the customer form their perception's on the logistics service provider. Also, in the logistics service context the literature presents that, customers who experienced multiple service failures are less satisfied than customers who only experienced one failure (van Doorn and Verhoef, 2008). Therefore, it can be concluded that professional b2b customers are stricter towards the inability to eliminate service failures. Moreover, first- time customers may increase failure occurrence probability as well (Michel, 2001), this is due to the customer's involvement in service supply process and the customer's inexperience since it's their first time.

\subsection{Service Recovery in Logistics Services}

The dedication to the service quality is vital for superior service recovery (Bell and Zemke, 1987). Service recovery is important in the logistics industry due to the industry's tendency to adopt proactive approach to service failure (Brinsmead, 2007). The service recovery research has been developing non- stop over the past 20 years with the rise of service economies and customer- 
focused strategies (Johnston and Michel, 2008) and it has focused on diverse aspects of service recovery (Craighead et al., 2004). Service literature represents that both service failure and service recovery strongly influence customer relationships (van Doorn and Verhoef, 2008).

Although service failure and service recovery are both crucial for the relationship between the company and its customer, the fact that customers are more dissatisfied with the company's failure to recover rather than the actual service failure must be stressed (Bitner et al, 1990; Berry and Parasuraman, 1991). Since, service providers attempt to decrease the negative emotions through effective recovery (Ozgen and Duman Kurt, 2012).

The most important factor for the service provider to consider when faced with a failure is to consider that the majority of the customers tend to avoid expressing their dissatisfactions (Boshoff, 1997). Therefore, it is crucial for the service providers not to limit their recovery efforts to post-complaint instances but rather follow up on every failure in some manner. On the other hand, it must be considered that unreported service failures may also prolong relationships since people who do not report failures may be more tolerant (van Doorn and Verhoef, 2008). The service recovery is significant since, poor customer retention creates financial implications. Moreover, this financial implication due to the inability to retain customers increases over time (Brinsmead, 2007). Thus, it must be avoided for the company's future.

In addition, service failures are not bound to create permanent negative outcomes if an effective recovery is carried out (Hart et al., 1989; Craighead et al., 2004). As mentioned before the selection of the aforementioned effective recovery strategy and the outcomes of the implemented recovery are highly affected by failure type (Levesque and McDougall, 2000; Chou et al., 2009; Craighead et al., 2004).

The service recovery is basically what the service providers do in response to a service failure (Grönroos, 1988; Weun et al., 2004). It is the process where aggrieved customers are once again satisfied with the company, after a service has failed their expectations (Zemke and Bell, 1990). The importance of service recovery for post-failure customer satisfaction is well established (Bitner et al., 1990; Smith et al., 1999; Tax et al., 1998, Keaveney, 1995). Since service failures and failed recoveries are the foremost reason behind customer switching behavior in service organizations 
(Keaveney, 1995), the importance of the issue is obvious. Moreover, service recovery is crucial in the sense that satisfaction is a significant determinant of key outcome variables related with relationship such as trust, commitment, word-of- mouth and longterm relationship (Bitner et al., 1990; Hart et al., 1989; Michel, 2001; Weun et al., 2004; Ok et al., 2005).

Service recovery is both a means to enhance customer satisfaction at the transaction-specific level and a relationship tool; hence it is extremely important and plays unique role in the service sector (Brown et al., 1996).

Furthermore, an effective recovery can only be undertaken matching it to the specific failure situation at hand (Craighead et al., 2004) and depends both on the company and the customer efforts (Boshoff, 1997). Moreover, the effectiveness of the recovery is correlated with the concept of exchange (Levesque and McDougall, 2000). In addition, service failure severity, the justice perceptions and attributions also play an important part in customers' perceptions on recovery (Bradley and Sparks, 2012).

Although the service recovery has also been classified under process and outcome of the recovery categories in B2C environments (Goodwin and Ross, 1989; Hoffman et al., 1995; Weun et al., 2004; Spreng et al., 1995; Goodwin and Ross, 1992; Smith et al., 1999; Mittal and Lassar, 1998; Webster and Sundaram, 1998; Zhu et al., 2004), the specific characteristics of B2B services require another approach. The outcome of service recovery is focused on the "tangible end result" whereas the process of service recovery is "the manner in which service provider handles" the problem during recovery (Weun et al., 2004).

Symbolic service recovery stands for the recovery that does not yield an economic outcome for the customer. The symbolic service recovery includes symbolic exchange such as an apology. However, it has been underlined that process service failures require a symbolic service recovery since its in kind with the experienced service failure (Smith et al., 1999).

Utilitarian service recovery yields an economic outcome for the customer after the service failure such as compensation, discount etc. Utilitarian service recovery is required when there has been an outcome (core) service failure. Since the outcome service failure creates an economic loss for the customer it needs a recovery which yields an economic gain in order to balance the relationship (Smith et al., 1999) and justice perceptions of customers. 
Another approach considers the symbolic service recovery as a process recovery and, utilitarian service recovery to be an outcome recovery matching to its failure counterpart (Zhu et al., 2004).

The term mixed service recovery represents the use of two or more of the above mentioned service recoveries. The main point is that both recovery types are utilized within one recovery effort simultaneously and the choice depends on the type of the service failure at hand (Chou et al., 2009).

Customer perceptions of buyer-seller relationships with the service provider effect their recovery strategy expectations excessively, which may shed a light on how some customers are satisfied and others are not when face with a similar recovery following the failure (Chou et al., 2009). If the service provider evaluates their relationship with the customer as good than they are willing to put more effort into maintaining it, hence, the recovery attempt as well (Chou et al., 2009). The service recovery efforts of a firm is perceived as high if they implement 2 or more recovery strategies hence a "mixed recovery strategy". Meaning, the firm could use a utilitarian strategy with an additional symbolic (Chou et al., 2009).

\subsubsection{Recovery Response Time}

Besides choosing and matching the appropriate recovery to its failure counterpart, the response time of the service provider also plays an important role in post-failure outcome. A recent study on recovery dimensions has shown that in customers' eyes the speed of recovery is the first item on the agenda in the recovery context (Battaglia et al., 2012). As it was pointed out, the shorter it takes to address the issue at hand; the less damage will be inflicted upon customer satisfaction and loyalty (Craighead et al., 2004; Hart, et al., 1990). Likewise, it was highlighted that the speedy responses have a greater chance to influence the customers' justice evaluations when the experienced service failure is less severe (Smith et al., 1999; Battaglia et al., 2012). Though receiving an effective recovery only yields satisfaction when it's received in time. A late recovery although the right type, is not considered very effective after all.

The impact of the inability to attain timeliness and delays in service recovery is evident in the literature (Hart et al., 1989; Spreng et al., 1995; Tax et al., 1998; Zemke and Bell, 1990; Taylor and Baker, 1994; Rio- Lanza et al., 2009; Battaglia et al., 2012). The short recovery response time refers to the ability to contain the problem quickly which will ease the customer's mind on the issue, considering 
the failure impacts the customer's operations (Battaglia et al., 2012) and build trust towards the logistics service provider. Also, considering the importance of timeliness for physical distribution service quality (Bienstock et al., 1996), it becomes clear that the sooner the recovery is implemented, the better outcomes it will yield for the logistics service provider.

Therefore, the sooner recovery takes place; the higher level of improvement in customer satisfaction is expected posterior to service recovery (Boshoff, 1997). Moreover, the importance of finding out about the failure and implementing a recovery as soon as possible has been stressed in both B2C and B2B contexts (Bell and Zemke, 1987; Boshoff, 1999; Miller et al., 2000; Craighead et al., 2004).

\subsection{Outcomes Posterior to Service Failure and Recovery}

According to the service quality literature the expected outcomes of service recovery on the customer are improved customer satisfaction and improved service quality perceptions followed by positive behavioral intentions namely: repeat purchases and loyalty (Boshoff, 1997). Further, recovery procedures have an impact on customer satisfaction and customer satisfaction has an impact on customer retention, whereas, customer retention has an impact on financial performance which leads to the assumption that customer satisfaction has an indirect impact on financial performance (Johnston and Michel, 2008).

Therefore, considering the importance of long-term customers from an economic point of view the overall strategy of the logistics service provider should focus on delivering superior service and creating customer value. To put it another way, the initial cost of acquiring new customers may be high due to generation cost, but as they stay with the company, the aforementioned cost spreads over time and each transaction becomes more profitable. Also, customers who prefer to stay are willing to spend more for service excellence. Customer loyalty also means positive feelings towards the company which means positive word of mouth (Boshoff, 1997) which will enable attracting new customers much easier.

It was also underlined that the change in customer relationships and satisfaction posterior to service failures varies with customers past experience with the company (Hess et al., 2003). Consequences regarding the effectiveness of recovery efforts can be accounted by the quality of recovery efforts just as much as the various relationship levels between the customer and the logistics 
service provider (Olsen and Johnson 2003). Customers with a strong relationship with the service provider have higher expectations for future interactions and show greater tolerance when failures occur since they believe that inequities caused by a service provider's unsatisfactory performance, a service failure, will equalize across future transactions. This buffering effect is based on the entire history of the customer and the service provider (Olsen and Johnson 2003). Also, the long past relationship with the logistics service provider is a sign of trust, mutual cooperation and integration. These all influence the customer's perception of the logistics service quality they receive and the logistics service provider, which in turn affect the future relationship between the customer and the logistics service provider.

The proposed four outcomes posterior to service failures and recovery are improved relationships, weakened relationships, adjourned relationships and relationships that are not influenced by the service failure and recovery (Edvardsson, 1992).

After a service failure and recovery is experienced, the customer may be inclined to improve the relationship with the service provider under certain circumstances. It is proposed that a good recovery and even a failure occurrence may increase the overall satisfaction of the customer if handled properly (Weun et al., 2004; van Doorn and Verhoef, 2008). The customer may be impressed by the punctuality and effectiveness of the service provider whilst dealing with a failure, how the service provider handled the failure and the recovery or just the outcome of the recovery. Hence, the customer will be willing to not only continue the existing relationship but enhance it due to an emerging trust for the business companion.

Some failures and/recoveries do not have an impact on the relationship between the two parties. This may be due to the long term relationship in between, the dependence structure or the power each party has over the other, the working agreement may a on a long term contract for all shipments of the customer, the insignificance of the failure or the service provider to the customer.

Another outcome of a service failure and recovery may be the weakened relationship between the service provider and it's customer due to loss of trust and the experienced cognitive dissonance. However, the service provider company and its customer may be working on a long term contract basis which does not let the business relationship die out and give the service provider new opportunities to win the customer back. 
The worst case scenario posterior to service failures and recovery is an adjourned business relationship between the service provider and the customer. This may be due to the failure' magnitude, frequency, prior experience with the service provider company, the ineffectiveness of the recovery, the recovery responsiveness, the experienced cognitive dissonance, the attribution of fault on the service provider company and the insignificance of the service provider for the customer.

\section{Conclusions}

The most significant determinant of logistics service quality is the logistics service provider's ability to satisfy their customers' needs and expectations. Only through satisfying or exceeding these expectations can they keep their customers satisfied and their businesses sustained. One of the most crucial obstacles against that goal is the gaps between the logistics service provider perspective and their customers'.

Another vital determinant in logistics service quality is the timeliness of the service delivery. This is mostly due to the unique nature of logistics services and the role timeliness and flexibility in effective and efficient logistics operations. Timeliness also influences customers' perception towards the service quality and the logistics service provider which in turn influence the company's market share and financial status.

Although customer retention and loyalty, thus, repeat customers hold crucial importance for service companies and the most effective way to ensure they stay is to provide sustainable high quality service. However, service delivery and its unique characteristics make it, at times, impossible to operate without fail. Even thought, service failure holds the potential for destroying loyalty, an effective recovery may enable to maintain or even increase loyalty after all (Miller et al., 2000) if they are handled appropriately and also in compliance with the customer's perceptions and expectations.

The fact that b2b service failures are even more critical due to their multiplied impact the occurrence of failures should be taken seriously. In addition, failure-proofing logistics services is almost impossible due to the high level of human involvement. Moreover, the involvement of the customer to the service delivery process is also another challenge for logistics service providers because whenever a failure occurs customers are most likely to be aware since in services the production and the consumption are 
simultaneous. Therefore, if the failure cannot be avoided the damage cause by the failure can be remedied through effective recovery strategies in kind with the failure type.

The recovery holds the potential to restore customer satisfaction and loyalty. Service recovery also creates a possibility to create trust between business parties since the customer' perceptions of the logistics service provider will be altered if the customer's mind is put to ease. Therefore, in a sense, service recovery is more important than the service failure and should be handled accordingly. In order for the recovery to succeed customer's prior experience with the logistics service provider and the recovery response time are significant factors to be considered.

The importance of recovery response time is especially elevated in logistics service providers case since logistics services are highly sensitive to time and the b2b environment increases the possible financial and operational impact of a failure to attain timeliness in logistics activities.

Finally, the impact of service failure and recovery on the service switching behavior of customers should be underlined. As mentioned before, some customers do not take the time to complain. Therefore, the proactive approach of logistics service providers will enable them to go beyond and satisfy their customers whilst nurturing loyalty and trust. The right recovery strategy following the same kind of failure must be pursued at the right time to avoid negative possible outcomes of the service failure and recovery situations like weakened or adjourned relationships which in turn will endanger the logistics service provider's ability to retain their customers, attract new ones, obtain competitive advantage, increase market share, increase profits and sustain their business.

\section{REFERENCES}

BAGOZZI, Richard P. (1975), "Social exchange in marketing". Journal of the Academy of Marketing Science 3(3), 314327.

BATTAGLIA, Daniel, Miriam BORCHARDT, Miguel AFONSO SELLITTO, and Giancarlo MEDEIROS PEREIRA, (2012). Service recovery: a method for assessing performance. Business Process Management Journal, 18(6),949-963.

BEAMON, Benita M. (1999). "Measuring supply chain performance." International Journal of Operations \& Production Management 19(3): 275-292. 
BELL, Chip R., and Ron E. ZEMKE, (1987). Service break down: the road to recovery. Management review, 76(10), 32.

BERRY, Leonard, L. and Anantharan PARASURAMAN, (1991). Marketing services: Competing through quality. New York: Free Press.

BIENSTOCK, Carol C., John T. MENTZER and Monroe M. BIRD, (1996). Measuring physical distribution service quality. Journal of the Academy of Marketing Science, 25(1), 31-44.

BITNER, Mary J., Bernard H., BOOMS and Mary S. TETREAULT, (1990). The service encounter: diagnosing favorable and unfavorable incidents. The Journal of Marketing, 71-84.

BLODGETT, Jeffrey G., Donna J. Hill, and Stephen S. Tax. (1997) "The effects of distributive, procedural, and interactional justice on postcomplaint behavior". Journal of retailing 73(2),185210.

BOLTON, Ruth. N. (1998). A dynamic model of the duration of the customer's relationship with a continuous service provider: The role of satisfaction. Marketing science, 17(1),45-65.

BOLTON, Ruth. N., and James H. DREW (1991). A multistage model of customers' assessments of service quality and value. Journal of consumer research,375-384.

BOLTON, Ruth. N., and James H. DREW (1992). Mitigating the effect of service encounters. Marketing Letters, 3(1),57-70.

BOSHOFF, Christo. (1999). Recovsat: An Instrument to Measure Satisfaction with Transaction-Specific Service Recovery. Journal of Service Research, 1(3), 236- 249.

BOSHOFF, Christo, and Jason LEONG, (1998). Empowerment, attribution and apologizing as dimensions of service recovery. International Journal of Service Industry Management, 9(1),24-47.

BOSHOFF, Christo. (1997), An experimental study of service recovery options, International Journal of Service Industry Management, 8(2), pp.110-130.

BRADLEY, Graham and Beverly SPARKS (2012). Explanations: if, when, and how they aid service recovery, Journal of Services Marketing, 21 (1), pp.41-50

BRINSMEAD, Andrew. (2007). Logistics Service Recovery and the role of Technology. In Communications and Information Technologies, 2007. ISCIT'07. International Symposium on (pp. 1361-1365). IEEE.

BROWN, Stephen W, Deborah L. COWLES and Tracy L. TUTEN, (1996), Service recovery: its value and limitations as a retail 
strategy, International Journal of Service Industry Management, 7(5) pp. $32-46$

CHOU Christine, Ya-Hui HSU and Yeong-Jia GOO (2009). Service Failures and Recovery Strategies from the Service Provider Perspective. Asia Pacific Management Review, 14(2),237-249.

CRAIGHEAD, Christopher W., Kirk R. KARVAN and Janis L. MILLER (2004), The effects of severity of failure and customer loyalty on service recovery strategies, Production Operation Management, 13 (4), pp. 307-321.

DEL RÍO-LANZA, Ana Belén, Rodolfo VÁZQUEZ-CASIELLES, Ana Ma DÍAZ-MARTÍN (2009). Satisfaction with service recovery: Perceived justice and emotional responses. Journal of Business Research, 62(8),775-781.

DURVASULA, Srinivas, Steven LYSONSKI, and Subhash C. MEHTA. (2000). "Business-to-business marketing service recovery and customer satisfaction issues with ocean shipping lines." European Journal of Marketing 34(3/4), 433-452.

EDVARDSSON, Bo. (1992). Service breakdowns: a study of critical incidents in an airline. International Journal of Service Industry Management, 3(4),17-29.

FLORES, Luis A. F.S, and Marcos A. M. PRIMO, (2008). Failure Recovery Management in Performance of Logistics Services in a B2B Context: A Case Study Using the 3PL Perspective. Journal of Operations and Supply Chain Management, 1(1),29-40.

GARVIN, David A. "What does product quality really mean." Sloan management review 26.1 (1984).

GILLY, Mary C., and Betsy D. GELB, (1982)"Post-purchase consumer processes and the complaining consumer." Journal of Consumer Research, 323-328.

GOODWIN, Cathy, and Ivan ROSS. (1989). "Salient Dimensions of Perceived Fairness in resolution of Service Complaints." Journal of Consumer Satisfaction, Dissatisfaction, and Complaining Behavior, 2,87-92.

GOODWIN, Cathy, and Ivan ROSS (1992). "Consumer responses to service failures: influence of procedural and interactional fairness perceptions." Journal of Business research 25(2),149-163.

GREMLER, Dwayne D. (2004). The critical incident technique in service research. Journal of service research, 7(1),65-89.

GRÖNROOS, Christian. (1982). "An applied service marketing theory." European journal of marketing 16(7), 30-41. 
GRÖNROOS, Christian (1988). Service quality: the six criteria of good perceived service. Review of business, 9(3),10.

GUNASEKARAN, Angappa, Chaitali PATEL, and Ercan TIRTIROGLU. (2001). "Performance measures and metrics in a supply chain environment." International journal of operations \& production Management 21(1/2), 71-87.

HARDING, Forrest E. (1998). "Logistics service provider quality private measurement, evaluation, and improvement." Journal of Business Logistics 19(1), 103.

HART, Christopher. W, James L. Heskett and W. Earl Sasser Jr, (1989). The profitable art of service recovery. Harvard business review, 68(4),148-156.

HESS, Ronald L., Shankar GANESAN, and Noreen M. KLEIN. (2003). "Service failure and recovery: the impact of relationship factors on customer satisfaction." Journal of the Academy of Marketing Science 31(2),127-145.

HOFFMAN, K. Douglas, Scott W. KELLEY, Holly M. ROTALSKY (1995). Tracking service failures and employee recovery efforts. Journal of Services Marketing, 9(2), pp.49-61

JOHNSTON, Robert, and Stefan MICHEL. (2008). "Three outcomes of service recovery: customer recovery, process recovery and employee recovery." International Journal of Operations \& Production Management 28(1), 79-99.

KAHNEMAN, Daniel and Amos TVERSKY (1979). Prospect theory: An analysis of decision under risk. Econometrica: Journal of the Econometric Society, 263-291.

KEAVENEY, Susan M. (1995). Customer switching behavior in service industries: An exploratory study. The Journal of Marketing,71-82.

LEVESQUE, Terrence J. and Gordon H.G. MCDOUGALL, (2000): "Service problems and recovery strategies: an experiment." Canadian Journal of Administrative Sciences, 17(1), 20-37.

LOVELOCK, Christopher and Jochen WIRTZ. Services Marketing: People, Technology, Strategy. Prentice Hall, 2011.

MCCOLLOUGH, Michael A., and Sundar G. BHARADWAJ (1992). The recovery paradox: an examination of consumer satisfaction in relation to disconfirmation, service quality, and attribution based theories. Marketing theory and applications,119.

MCCOLLOUGH, Michael A., Leonard L. BERRY and Manjit S. YADAV (2000). An empirical investigation of customer satisfaction 
after service failure and recovery. Journal of service research, 3(2),121-137.

MENTZER, John T., William DEWITT, James S. KEEBLER, Soonhong MIN, Nancy W. NIX, Carlo D. SMITH and Zach G. ZACHARIA, (2001). Defining supply chain management. Journal of Business logistics, 22(2), 1-25

MICHEL, Stefan. (2001). Analyzing service failures and recoveries: a process approach. International Journal of Service Industry Management, 12(1),20-33.

MILLER, Janis L., Christopher W. CRAIGHEAD and Kirk R. KARVAN (2000). Service recovery: a framework and empirical investigation. Journal of operations Management, 18(4),387-400.

MITTAL, Banwari, and Walfried M. LASSAR, (1998). "Why do customers switch? The dynamics of satisfaction versus loyalty." Journal of services marketing,12(3), 177-194.

MOHR Lois A., and Mary J. BITNER (1995). The role of employee effort in satisfaction with service transactions. Journal of Business Research, 32(3),239-252.

MURRAY Keith B and John L. SCHLACTER (1990). The impact of services versus goods on consumers' assessment of perceived risk andvariability. Journal of the Academy of Marketing Science, 18(1),51-65.

OFLAÇ, Bengü S., Ursula Y. SULLIVAN, and, Tunçdan BALTACIOĞLU. (2012). "An attribution approach to consumer evaluations in logistics customer service failure situations." Journal of Supply Chain Management 48(4),51-71.

OK, Chihyung, Ki-Joon BACK, Carol W. SHANKLIN, (2005). Modeling roles of service recovery strategy: a relationship-focused view. Journal of Hospitality and Tourism Research, 29(4),484-507.

OLSEN, M and B THOMASSON (1992). Qualitative Methods in Service Quality Research: An Illustration of the Critical Incident Technique and Phenomenography'. In QUIS3 Conference (pp.14-17).

OZGEN, Özge and Sümeyra DUMAN KURT (2012). Prerecovery and post-recovery emotions in the service context: a preliminary study. Managing Service Quality: An International Journal, 22(6),592-605.

ÖZTÜRK Sevgi A. (2000). Hizmet Kalitesi Ölçümünde Yeni Bir Yaklaşım: Kritik Olaylar Tekniği. Anatolia: Turizm Araştırmaları Dergisi, 11,57-68.

PANAYIDES, Photis M., and Meko SO (2005). "The impact of integrated logistics relationships on third-party logistics service 
quality and performance." Maritime Economics \& Logistics 7.1, 3655.

PARASURAMAN Ananthanarayanan Valarie. A ZEITHAML and. Leonard, L. BERRY, (1998). "Servqual." Journal of retailing 64(1),12-40.

PARASURAMAN Ananthanarayanan Valarie. A ZEITHAML and. Leonard, L. BERRY (1985). A conceptual model of service quality and its implications for future research. the Journal of Marketing, 4150 .

PRIMO, A.M. Marcos, Kevin DOOLEY and Johnny M. RUNGTUSANATHAM (2007). Manufacturing firm reaction to supplier failure and recovery. International Journal of Operations and Production Management, 27(3),323-341.

QURESHI, M. N., Dinesh KUMAR and Pradeep KUMAR (2007). "Modeling the logistics outsourcing relationship variables to enhance shippers' productivity and competitiveness in logistical supply chain." International Journal of Productivity and Performance Management 56.8, 689-714.

RICHINS, Marsha L. (1987)"A multivariate analysis of responses to dissatisfaction. "Journal of the Academy of Marketing Science 15(3,) 24-31.

GIL SAURA, Irene, David SERVERA FRANCES, Gloria BERENGUER CONTRI, Maria FUENTES BLASCO (2008). Logistics service quality: a new way to loyalty. Industrial Management \& Data Systems, 108(5), 650-668.

SMITH Amy K., Ruth N. BOLTON, and Janet Wagner (1999). A model of customer satisfaction with service encounters involving failure and recovery. Journal of marketing research,356-372.

SPRENG, Richard A., Gilbert D.; HARRELL and Robert D, MACKOY, (1995). Service recovery: impact on satisfaction and intentions. Journal of Services Marketing, 9(1),15-23.

STEWART, Gordon. (1995). Supply chain performance benchmarking study reveals keys to supply chain excellence. Logistics Information Management, 8(2), 38-44.

SWANSON, Scott R. and Maxwell K. HSU (2009) Critical Incidents in Tourism: Failure, Recovery, Customer Switching, and Word -of-Mouth Behaviors, Journal of Travel and Tourism Marketing, 26 (2),180-194.

TAX, Stephen S., Stephen W. BROWN and Murali CHANDRASHEKARAN (1998). Customer evaluations of service 
complaint experiences: implications for relationship marketing. The Journal of Marketing,60-76.

TAYLOR, Steven A., and Thomas BAKER (1994). An assessment of the relationship between service quality and customer satisfaction in the formation of consumers' purchase intentions. Journal of retailing, 70(2),163-178.

THALER, Richard (1985). Mental accounting and consumer choice. Marketing science, 4(3), 199-214.

VAN DOORN, Jenny, and Peter C. VERHOEF (2008). Critical incidents and the impact of satisfaction on customer share. Journal of Marketing, 72(4),123-142.

WEBSTER, Cynthia and Dinesh S. SUNDARAM (1998). Service consumption criticality in failure recovery. Journal of Business Research, 41(2),153-159.

WEUN, Seungoog, Sharon E.; BEATTY and Michael A. JONES (2004) The impact of service failure severity on service recovery evaluations and post-recovery relationships. Journal of Services Marketing. 18(2). pp133-146

YANAMANDRAM, Venkata K., and Lesley WHITE. (2007) "A Model of Customer Retention of Dissatisfied Business Services Customers." Faculty of Commerce-Papers.

ZEITHAML, Valerie. A., Lenonard L. BERRY and Anantharanthan PARASURAMAN, A. (1996). The behavioral consequences of service quality. the Journal of Marketing,31-46.

ZEMKE, Ron and Chip R. BELL (1990). Service recovery: Doing it right the second time. Training, 27(6),42-48.

ZHU, Zhen, K. SIVAKUMAR, and Anantharanthan PARASURAMAN (2004). A Mathematical Model of Service Failure and Recovery Strategies. Decision Sciences, 35(3),493-525. 